\title{
Classification of Tupí-Guaraní
}

\author{
Aryon Dall'Igna Rodrigues
}

Norman McQuown has recently published a synthesis of J. Alden Mason's classification of South American languages. ${ }^{1}$ Although everyone will acknowledge the importance of the systematic work of both Mason and McQuown, one cannot help feeling that Taylor's criticism concerning the West Indies, 'the present classification... complicates and obscures the perspective unnecessarily'2, can be applied in part also to South America. I am presently concerned with Tupí-Guaraní, for which this opinion is particularly valid. I do not consider the Macro-Tupí-Guaraní phylum which, as put forth 'very tentatively' by Mason and accepted by McQuown, includes 'Huitotoan' and 'Zaparoan', because I have not as yet found any linguistic evidence for such a phylum. I limit my comments to Tupí-Guaraní proper. In this group, McQuown's paper reproduces exactly Mason's tabulation, without any critical revision, but including mistakes as well as misprints (cf. for example the inclusion of Torá and the classification of Camaiurá as 'Tapajoz Tupian').

It seems to me that McQuown, in trying to present 'the full list of Latin American indigenous languages', has erred in giving the status of 'language' to many local group names. Thus, eighteen 'languages', fourteen of which are presented as 'relatively important' (they are distinguished by numbers on the map), are listed as Coastal Tupian: Tupina (= Tupiguae), Aricobe, Amoipira, Apigapigtanga, Araboiara, Caete, Guaracaio (= Itati), Muriapigtanga, Potiguara (= Pitonara), Rariguara, Tamoio, Timimino (= Temimino), Tobajara

1. Norman McQuown, The indigenous languages of Latin America, AA 57.501-570 (1955); J. Alden Mason, The languages of South American Indians, Handbook of South American Indians, 6.157-317 (Washington 1950).

2. Douglas Taylor, Languages and ghost-languages of the West Indies, IJAL 22.180-183 (1956), p. 180. 
$(=$ Tabayara $=$ Toboyara $)$, Tupiniquin $(=$ Tupinaqui $=$ Tupinqui $)$, Viatan $(=$ Pernambuco), Tamoia? (= Tamoio), Tupi, Tupinambá. This is properly a list of the local groups of Tupinambá Indians who lived in Eastern Brazil in the $16^{\text {th }}$ and $17^{\text {th }}$ centuries (except Guaracaio or Itati, which is not Tupinambá but Guaraní), as is stated in the ethnological monographs of Métraux. ${ }^{3}$ According to the $16^{\text {th }}$ and $17^{\text {th }}$ century sources these groups all spoke the same language, which the Portuguese called 'língua geral', i.e. the general language of the Brazilian Coast. (In order to distinguish the língua geral from other Tupí languages, I have proposed for it the name Tupinambá.) $)^{4}$ There were of course dialectal variants in an area that extended from about $S 1^{\circ}$ to $S 22^{\circ}$, but the known evidence shows that such variants were very slight. But the MasonMcQuown list is not based on probable linguistic or dialectal differences. It is simply a list of names. All groups that are known under a distinct name figure in the list as distinct entities, all groups that have the same name as unified as one entity irrespective of their geographical distribution.

Under Tupinambá 'language' are listed, for example, the three groups known as 'Tupinambá': the Tupinambá of Maranhão (S $1^{\circ}-3^{\circ} 30^{\prime}$, W 44든 $\left.49^{\circ}\right)$, the Tupinambá of Bahia $\left(\mathrm{S} 11^{\circ}-15^{\circ}, \mathrm{W} 37^{\circ}-40^{\circ}\right)$, and the Tupinambá of Rio de Janeiro (S $\left.22^{\circ}, \mathrm{W} 41^{\circ}-45^{\circ}\right)$. Though the Tupinambá of Maranhão and those of Rio de Janeiro lived at the very extremes of the area, they are given the same language. But the Tamoio of Rio de Janeiro $\left(\mathrm{S} 22^{\circ}\right.$, W $\left.41^{\circ} 30^{\prime}-45^{\circ}\right)$, which according to the sources (cf. Métraux, loc. cit.) are the same as the Tupinambá of Rio de Janeiro, are given a distinct 'Tamoio language'. Father Joseph de Anchieta, one of the most reliable sources on the lingua geral, distinguishes in his grammar (published in 1595, when the author had already more than forty years of experience in Eastern Brazil) only two dialects: that of the Indians extending from the Pitiguara (in Pernambuco, about $S 6^{\circ}-8^{\circ}$ ) to the Tamoio (in Rio de Janeiro, about S $23^{\circ}$ ), and that of Tupí (in S. Vicente, about $\left.\mathrm{S} 23^{\circ}-24^{\circ}\right){ }^{5}$ Sources documenting the lingua geral on various points of the Brazilian Coast (Anchieta: Rio de Janeiro to Bahia, Léry ${ }^{6}$ : Rio de Janeiro, Marcgrave $^{7}$ : Pernambuco, Figueira ${ }^{8}$ : Northeast, Abbeville ${ }^{9}$ and Evreux ${ }^{10}$ :

3. Alfred Métraux, La civilisation matérielle des tribus Tupi-Guarani, p. 12-19 (Paris 1928); id., The Tupinambá, Handbook of South American Indians 3.95-97 (Washington 1948).

4. Aryon D. Rodrigues, A nomenclatura na família Tupí-Guaraní, Boletín de Filología 43/45.98-104 (Montevideo 1950).

5. Joseph de Anchieta, Arte de grammatica da lingua mais usada na costa do Brasil, fl. lv. (Coimbra 1595).

6. Jean de Léry, Histoire d'un voyage faict en la terre du Brésil, nouvelle édition par Paul Gaffarel, 2 vols. (Paris 1880).

7. Jorge Marcgrave, História natural do Brasil, trad. de J. P. Magalhães (São Paulo 1942). 
Maranhão) demonstrate the remarkable uniformity of the language in this vast territory. The only distinction made is that of Anchieta, who remarks that the Tupí of S. Vicente spoke a dialect sharing some characteristics with the Guaraní (loss of final consonants). The speech of the Tupí was therefore not only a geographical intermediary, but probably also a linguistic one between Tupinambá and Guaraní. Whether some of groups listed by Mason-McQuown actually spoke a dialect other than Tupinambá (or Old Tupí) language with only very slight local variations, the other 14 'relatively important' Coastal Tupian languages of McQuown's list are nothing more than 'ghost languages'.

A similar situation arises for McQuown's Guaraní and Cainguan. Under Cainguan are listed among others Apapocuva, Oguiva or Oguaiva, and Tanygua. Nimuendajú, the only source (and a good one) for the language of these groups, says: 'Genau den gleichen Dialekt wie die Apapocúva sprechen auch die Tanyguá und Oguauíva', a statement that, of course, does not exclude the possibility of minor variations, as, for example, the difference in stress pointed out by Nimuendajú himself. ${ }^{11}$

Mason's internal classification of Tupí-Guaraní is predominantly geographic, not linguistic, and therefore does not correspond to the premises set up in the excellent methodological introduction to McQuown's paper. McQuown himself says that 'no documented study of the internal divisions of Tupí-Guaraní on a linguistic basis has been made' (p. 560). The major linguistic defect of Mason-McQuown's classification is the distribution of all Tupí-Guaraní languages in two great divisions, Tupí and Guaraní. Since Tupí and Guaraní, i.e. Tupinambá and Old Guaraní, are very closely related to one another ( $90 \%$ common vocabulary in the 200 item list of Swadesh), it is evident that they cannot give the key for the bipartion of the totality of languages involved in this large and higher differentiated linguistic stock. In this particular, the Mason-McQuown classification is inferior to that of Loukotka. ${ }^{12}$

8. Luis Figueira, Arte de grammatica da lingua brasilica (Lisboa 1687).

9. Claude d'Abbeville, História da missão dos padres capuchinhos na ilha do Maranhão, trad, de S. Milliet (São Paulo n.d.).

10. Yves d'Evreux, Voyage dans le Nord du Brésil fait durant les années 1613 et 1614 (Leipzig and Paris 1864).

11. Curt Nimuendajú-Unkel, Die Sagen von der Erschaffung und Vernichtung der Welt als Grundlagen der Religion der Apapocúva-Guaraní, Zeitschrift für Ethnologie 46.284-403 (1914); see p. 299.

12. Čestmír Loukotka, Klassifikation der südamerikanischen Sprachen, Zeitschrift für Ethnologie 74.1-69 (1944). 
The subdivisions of Mason-McQuown's Guaranian and Tupian are also predominantly geographic and present great linguistic inconsistency. Thus, for example, Guaraní and Tupinambá (with $90 \%$ common basic vocabulary) are separated as members of the two major divisions, but Tupinambá and Šipaya (with $21 \%$ common basic vocabulary) are in the same division, and Sipaya and Ramarama (with $14 \%$ common basic vocabulary) are in the same subdivision in which Wirafed is also placed. Note however that WirafedSipaya have not only $24 \%$ common basic vocabulary and Wirafed-Ramarama only $18 \%$ and that Wirafed shares $71 \%$ of its basic vocabulary with Tupinambá, which belongs to another subdivision. ${ }^{13}$

My own classification of Tupí-Guaraní (given at the $32^{\text {nd }}$ International Congress of Americanists, Copenhagen, 1956) differs in many particulars from that offered by Mason and McQuown. I have put forth a Tupí stock composed of several families, one of which is Tupí-Guaraní proper. This stock is more inclusive than the Tupí-Guaraní family of Rivet, Loukotka and Mason-McQuown, but it does not correspond to Mason's Macro-TupíGauraní phylum.

The major criterion for my classification is lexical similarity. It is not a final classification: some languages, usually considered in this group, are omitted because I have not yet made a thorough examination of the data. As a first attempt, my classification is certainly subject to improvement, and I shall welcome suggestions to this end.

Divisions and subdivisions in my classification are made roughly according to the following lexicostatistical criterion: ${ }^{14}$ stock $=12 \%$ or more cognate basic vocabulary, family (symbolized by a capital) $=36 \%$ or more, subfamily (a minuscule $)=60 \%$ or more language (an arabic figure) $=$ up to $81 \%$ (dialect) $(\mathrm{a}$ Greek letter) $=81 \%$ or more. Different historical phases of the same language or local varieties of a dialect are designed by Romanic figures.

Some modifications of detail were made in this classification since it was first presented in 1956. A question mark indicates doubt as to the position of the language in the family, but not as to its inclusion in the stock.

13. On the lexical relationships see A. D. Rodrigues, As línguas 'impuras' da família Tupí-Guaraní, Anais do XXXI Congr. Internacional de Americanistas, p. 1055-1071 (São Paulo 1955)

14. Based on the criteria suggested by Morris Swadesh, Towards a satisfactory genetic classification of Ameridian languages, Anais do XXXI Congr. Internacional de Americanistas, p. 1001-1012 (São Paulo 1955); see p. 1010. 


\section{A. Tupí-Guaraní}

a. 1. Tupí-Guaraní: $\alpha$. Tupí (i. Tupinambá or old Tupí, ii. Ñeengatú or Modern Tupí); $\beta$. Guaraní (i. Old Guaraní, ii. Avañeẽ or Modern Guaraní);

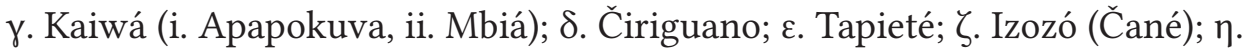
Guarayú.

a. 2. Tenetehara: $\alpha$. Tembé; $\beta$. Gwažažara; $\gamma$. Urubú; $\delta$. Manazé; $\varepsilon$. Turiwara; $\zeta$. Anambé.

a. 3. Oyampí: $\alpha$. Oyampí; $\beta$. Emérillon.

a. 4. Kawaíb: $\alpha$. Wirafed; $\beta$. Pawaté; $\gamma$. Parintintin.

a. 5. Apiaká.

a. 6. Kamayurá.

a. 7. Awetí.

a. 8. Tapirapé.

a. 9. Šetá (Aré).

a. 10. Pauserna.

a. 11. Kayabí (?)

a. 12. Canoeiro (Abá) (?)

a. 13. Takuñapé (?)

b. 1. Kokama: $\alpha$. Kokama; $\beta$. Kokamilla.

b. 2. Omagua.

c. Guayakí.

d. Maué.

e. 1 . Mundurukú ${ }^{15}$

e. 2. Kuruaya.

f. Sirionó (?).

\section{B. Yuruna}

a. 1. Yuruna.

a. 2. Šipaya.

b. Manitsawá.

C. Arikem

1. Arikem.

2. Karitiana.

3. Kabišiana (?).

\section{Tuparí}

1. Tuparí.

2. Guaratégaya (Koaratira, Gauratira, Amniapé, Mequéns, Kanoé)

15. Perhaps rather a family aside Tupí-Guaraní than a subfamily inside it. 
3. Wayoró: $\alpha$. Wayoró (Ayurú); $\beta$. Apičum.

4. Makurap.

5. Kepkiriwat.

\section{E. Ramarama}

1. Ramarama: $\alpha$. Ramarama; $\beta$. Ntogapid.

2. Urukú

3. Urumí

4. Arara

\section{F. Mondé}

1. Mondé: $\alpha$. Mondé; $\beta$. Sanamaikã (Salamãi).

2. Digüt.

3. Aruá: $\alpha$. Aruá; $\beta$. Aruáši.

G. Puruborá. 